\title{
EL MODELO FRANCÉS EN LA CONSTRUCCIÓN DEL ESTADO ESPAÑOL: EL MOMENTO MODERADO' ${ }^{1}$ The French Model in the Construction of the Spanish State: The Moderate Moment
}

\author{
JUAN PRO \\ Universidad Autónoma de Madrid \\ juan.pro@uam.es \\ Cómo citar/Citation \\ Pro, J. (2017). \\ El modelo francés en la construcción del Estado español: \\ el momento moderado. \\ Revista de Estudios Políticos, 175, 299-329 \\ doi: http://dx.doi.org/10.18042/cepc/rep.175.10
}

\section{Resumen}

La construcción del Estado en España tuvo en la primera mitad del siglo xIX un momento especialmente intenso de definición de sus bases doctrinales y de los grandes rasgos de su estructura institucional y territorial. Tras un primer impulso bajo el gobierno reformista del último periodo de Fernando VII, fue en el reinado de Isabel II cuando se dieron los pasos decisivos, bajo la hegemonía política del partido moderado. En ambos periodos, la influencia francesa fue notoria. Autores como Sáinz de Andino, Burgos, Silvela, Ortiz de Zárate, Oliván y Colmeiro tomaron el modelo de Estado de Francia para sustentar un giro político conservador después de desalojar a los progresistas del poder y poner fin a las grandes medidas de la revolución liberal española. La apropiación del modelo francés incluía tanto fórmulas institucionales concretas como un concepto de Estado identificado con la Administración, y también un tipo de Administración específico, fuertemente centralizado, que era el resultado de las reformas de la Monarquía de Julio sobre el modelo napoleónico.

\footnotetext{
1 Este artículo ha sido realizado en el marco del proyecto HAR2012-32713 del Plan
} Nacional de I+D+i. 


\title{
Palabras clave
}

Construcción del Estado; Estado-nación; España; Francia; siglo xıx.

\begin{abstract}
In the first half of the nineteenth century the construction of the Spanish State had an especially intense moment of definition, both of its doctrinal basis and of the broad strokes of its institutional and territorial structure. After a first effort under the reformist government during the final period of Fernando VII, it was during the reign of Isabel II that the decisive steps were taken, now under the political hegemony of the moderate party. During both periods, French influence was notorious. Authors like Sainz de Andino, Burgos, Silvela, Ortiz de Zárate, Oliván, and Colmeiro took up the French model of State to sustain a conservative political turn, following the eviction of the progressives from power, putting an end to the major initiatives of the Spanish liberal revolution. The appropriation of the French model included both specific institutional formulas such as the concept of State identified with the Administration, and a specific type of strongly centralized Administration, which was the result of the reforms of the Napoleonic model by the July Monarchy.
\end{abstract}

\section{Keywords}

State-building; Nation-State; Spain; France; Nineteenth Century. 


\section{SUMARIO}

I. ILUSTRACIÓN Y REVOLUCIÓN. II. LOS ORÍGENES AFRANCESADOS DEL ADMINISTRATIVISMO ESPAÑOL. III. VÍAS Y FACTORES DE CIRCULACIÓN DEL MODELO. IV. LOS ADMINISTRATIVISTAS DEL MOMENTO MODERADO. V. DEL MODELO FRANCÉS A LA REALIDAD ESPAÑOLA. VI. LA MADUREZ DEL SISTEMA Y SUS MATIZACIONES. VII. UN BALANCE DE LA REAPROPIACIÓN DEL MODELO FRANCÉS. BIBLIOGRAFÍA.

La construcción del Estado en España, como en otros países, ha sido resultado de una pugna entre proyectos dispares que pretendían orientar el proceso. Diversos imaginarios de Estado influyeron en mayor o menor medida en el resultado, en función de las circunstancias históricas y de la relación de fuerzas entre los grupos que los patrocinaban; pero ninguno obtuvo un triunfo completo, en el sentido de lograr que se construyera un Estado inspirado por un único modelo. En la medida en que los imaginarios concurrentes en la construcción histórica del Estado español contemporáneo contenían una valoración de los ejemplos a los que se podía mirar en otros países, el proceso no siguió la pauta de un único modelo de Estado extranjero.

Fueron varias las fuentes de inspiración europeas; pero entre todas ellas la de Francia fue sin duda la influencia predominante, tal vez como efecto de una influencia francesa más general sobre España, sostenida - tanto en el plano cultural como político- a lo largo de los siglos XVIII y XIX. Sin desdeñar la existencia de admiradores del modelo británico, que ocasionalmente hicieron notar esa inspiración, ni la ocasional mirada de los constructores del Estado español hacia doctrinas y soluciones institucionales procedentes de otros espacios europeos como Alemania, Italia o los Países Bajos, este trabajo pretende señalar las modalidades específicas de apropiación del modelo de Estado francés, cuya penetración en el imaginario jurídico y político de la España del xix fue tan profunda que cabe considerarla hegemónica por comparación con cualquier otro modelo de referencia.

Más allá de la similitud formal con originales franceses en muchas de las instituciones estatales que se crearon en España a lo largo del siglo XIX -y especialmente en el periodo álgido de construcción del Estado durante la década moderada (1844-1854)—, hubo una apuesta por algo más general, que se ha dado en llamar el modelo francés. Ese modelo implica hacer del Estado un tutor con influencia predominante sobre la sociedad y sus 
actividades; un Estado uniforme y centralista, que actúa directamente a través de la Administración pública y que se identifica con ella: el Estado es la Administración. En ese modelo, los cuerpos intermedios son un obstáculo que debe ser eliminado para dejar expedita la acción del Estado, único representante legítimo de los intereses colectivos; y esa acción es de la mayor importancia, pues el Estado está llamado, mediante la Ley y la Administración, a reconstruir la realidad del país en una dirección determinada (Rosanvallon, 2007: 12-17).

Al mismo tiempo, se intentará mostrar que esa inspiración francesa sobre las grandes líneas que definieron el Estado nacional construido en España en el siglo XIX ni fue constante ni constituyó una mera imitación. No fue constante, puesto que la inestabilidad de gobiernos y regímenes que caracterizó a la España decimonónica puso alternativamente en el poder a personas y partidos con miradas distintas hacia la experiencia de otros países, y fue en el periodo de hegemonía política del Partido Moderado durante el reinado de Isabel II cuando esa admiración por el modelo francés se hizo notar con toda su fuerza. Por otro lado, no fue una mera imitación, puesto que, a pesar de los discursos admirativos y de la referencia frecuente a ejemplos franceses, la apropiación fue selectiva y conllevó una adaptación de las piezas originales a las circunstancias españolas de aquel momento, interpretadas a través de los intereses que representaba el moderantismo.

No cabe duda de que en Francia, como en cualquier país, el modelo de Estado que se fue imponiendo históricamente fue objeto de controversias intelectuales y de luchas de poder ${ }^{2}$. No hubo - obvio es decirlo- un concepto unívoco de la Administración Pública ni una sola forma de entender el Estado ${ }^{3}$. Sin embargo, en la circulación de ideas y modelos entre uno y otro país es frecuente pasar por alto en gran medida ese pluralismo que en todas partes existe y, borradas las diferencias de origen, identificar a la corriente dominante como modelo de referencia. En el caso que nos ocupa, la recepción del modelo francés acabaría produciéndose a partir de una lectura selectiva del administrativismo de aquel país, realizada unilateralmente por un grupo de autores entre los que había una marcada sintonía de cultura política.

2 Lorente (2009), por ejemplo, ha recordado una de estas intensas controversias jurídicas sostenidas en Francia, a propósito del debate de 1814-1830 sobre la constitucionalidad del Consejo de Estado y la naturaleza del gobierno representativo.

3 Esta diversidad original del «laboratorio» francés ha sido puesta de manifiesto por Mannori y Sordi (2001), entre otros. 


\section{ILUSTRACIÓN Y REVOLUCIÓN}

La penetración de conceptos franceses en la doctrina y la práctica españolas sobre la administración se había iniciado ya en el siglo xviII, vinculada a las dos grandes innovaciones de la época: el derecho natural y la ciencia de la policía. No obstante, y aunque ambas corrientes penetraron y tuvieron incidencia en autores españoles, la universidad española fue bastante refractaria a las dos. La tradición del derecho común, con la novedad del estudio del derecho patrio a partir de 1741, ganó ampliamente la partida a un derecho natural y de gentes que, tras un momento de implantación incipiente bajo los gobiernos reformistas de Carlos III, pareció demasiado peligroso en términos políticos y fue proscrito a partir de 1794 (Pro, 2014).

Algo parecido ocurrió con el concepto de policía, cuya penetración fue también superficial y se limitó a albergar bajo un nuevo vocablo concepciones más tradicionales de la monarquía española, como era la del gobierno político y económico de los pueblos. Ciertamente, el concepto de policía había venido apareciendo en obras españolas de los siglos XVI, XVII y XVIII, como traslación de su uso en Europa continental, tanto en Francia como en Alemania ${ }^{4}$. En algunas ocasiones, policía parece haberse utilizado como sinónimo del buen orden de las ciudades que los gobernantes deben promover, por lo que incluye todas las funciones que en España se venían denominando de gobierno político y económico de los pueblos, sin añadir matices a este concepto tradicional. Otras veces, policía se usaba en un sentido más restringido, que se limita a las políticas de seguridad, sanidad y aseo de las ciudades, manteniendo el término de gobierno político y económico para el conjunto de la administración civil de nivel local.

Ese significado restringido, distinto del que predominaba en Francia, sería de uso creciente a partir del quiebro que supuso el motín contra Esquilache de $1766^{5}$. Desde entonces, el término policía sería de uso más frecuente ${ }^{6}$, pero ya referido de forma predominante al control institucionalizado del orden público. Así, por ejemplo, se utilizó para denominar la Superintenden-

4 Como han acreditado González Alonso (1995), Sánchez León (2005) y García Monerris (2008). En esta última obra, las autoras subrayan el cambio producido en el siglo XVII, ligado a la desacralización del poder y la aparición de la "razón de Estado".

5 Sánchez León (2005) pone de relieve este cambio a partir de 1766, cuando la vinculación del orden con el comercio - presente en autores como Campomanes o Bernardo Ward- dejó paso a visiones de la policía más vinculadas a la institucionalización del control social; repliegue defensivo que mostraría las limitaciones del reformismo ilustrado.

6 Por ejemplo, en Vizcaíno (1781) y Dou (1800-1803). 
cia General de Policía (vigente en 1782-1792 y recreada luego dos veces, por Carlos IV en 1807 y por Fernando VII en 1824), pues aquella policía no reunía las competencias de fomento de la economía que implicaría el concepto original francés, acercándose más al sentido actual de la policía de seguridad Un caso aparte sería la obra de Valeriola (1798), mera traducción de una de las obras francesas fundamentales sobre esta materia, el Traité de la Police de Delamare (1705-1738). En cualquier caso, se deduce de estos usos que, aunque el concepto de policía convivió con el más castizo de gobierno político y económico de los pueblos en la España de finales del Antiguo Régimen, no caló en el análisis ni en el enfoque de los asuntos de gobierno, estructurado en España en torno a este otro concepto más localista, que resistió bien a la novedad.

Fue la Constitución de Bayona — cuya inspiración francesa está fuera de duda - la que dio carta de naturaleza legal en España al concepto de policía en 1808, al crear un ministerio con esa denominación. Se trataba de la culminación de la lectura restrictiva del concepto, limitándolo a las funciones represivas y de control del orden público; pues al mismo tiempo se creaba un Ministerio del Interior que desempeñaría las funciones de administración civil $\mathrm{y}$ fomento de la riqueza ${ }^{8}$. De esta manera, se desgajaban en dos las funciones gubernativas que tradicionalmente se había atribuido a una autoridad única (Pro, 2008: 231-249). La Constitución de Cádiz rompió en 1812 con el concepto francés y, al denominar de Gobernación del Reino a la Secretaría encargada del orden público, enlazó de forma más directa con la tradición hispana del gobierno político y económico de los pueblos. No solo por el término elegido para dar nombre al ministerio, sino sobre todo porque volvía a reunir en una misma mano las funciones de seguridad y las de impulso a la vida económica. No obstante, ni el esquema ministerial de José Bonaparte ni el de las

7 Real Cédula de S.M. y Señores del Consejo de 17 de marzo de 1782 por la que se dispone la creación de una Superintendencia General de Policía para Madrid y su Rastro (Archivo Histórico Nacional, Consejos, lib. 1525, 33); Real Cédula de 13 de junio de 1792 por la cual se suprime la Superintendencia General de Policía de Madrid y su Rastro (Gaceta de Madrid, 51, 26 de junio de 1792, p. 424); Real Cédula de S.M. y Señores del Consejo de 13 de diciembre de 1807 por la cual se manda guardar y cumplir el Real Decreto en que se restablece la Superintendencia General de Policia de Madrid, su jurisdicción y su rastro (Biblioteca Nacional, R/34927, p. 137). Real Cédula de S.M. y Señores del Consejo de 13 de enero de 1824 mandando guardar y cumplir el Real decreto inserto para el establecimiento de la Superintendencia de la Policía del Reino (Archivo Histórico Nacional, Reales Cédulas, 3.824).

8 Constitución de 1808, art. 27. Real Decreto de 6 de febrero de 1809 (Prontuario..., I: $10-11$ y 83-94). 
Cortes de Cádiz se mantuvieron tras la desaparición de ambos regímenes. La restauración de la monarquía absoluta por Fernando VII significó inicialmente la vuelta a las instituciones del Antiguo Régimen con su sistema de gobierno jurisdiccional, que en la práctica había dejado de funcionar y se mostraba a todas luces inadecuado para hacer frente a los nuevos desafíos del momento.

\section{LOS ORÍGENES AFRANCESADOS DEL ADMINISTRATIVISMO ESPAÑOL}

La solución que pasaba por levantar una administración que pusiera orden en el país, aunque viniera lastrada por su origen francés y por haber sido adoptada en el marco de la revolución liberal, acabó por ser asumida por los gobiernos del último periodo de Fernando VII como antídoto contra la revolución. En un momento de crisis profunda del absolutismo, atrapado entre la inoperancia de las viejas instituciones, las conspiraciones liberales y la resistencia de los ultras a cualquier tipo de cambio institucional, la monarquía encontró una posible salida en la vía reformista consistente en reforzar y racionalizar la administración (Luis, 2002). Esa vía la encarnó desde el Gobierno Luis López Ballesteros, ministro de Hacienda entre 1823 y 1832. Resulta significativo que dos de sus colaboradores más destacados fueran antiguos afrancesados, como Javier de Burgos y Pedro Sáinz de Andino: ellos plantearon algunas de las más importantes líneas de reforma, en las que se adivinan ya los fundamentos del futuro Estado administrativo que se iba a construir tras el cambio de régimen'. Si el primer paso se había dado en $1823^{10}$, con la creación de la Presidencia del Consejo de Ministros, llamada a dar un sentido de conjunto a la acción del Gobierno, el paso decisivo fue la creación de la Secretaría de Estado y del Despacho del Fomento General del Reino en $1832^{11}$.

La solución adoptada entonces no fue la de las Cortes de Cádiz, que habían apostado por mantener un departamento gubernativo indiferenciado para todas las cuestiones de «interior», en la tradición española. La solución de

9 Javier de Burgos había colaborado con el régimen de José Bonaparte como subprefecto de Almería. Y Sáinz de Andino había sido sucesivamente secretario general de la Subprefectura de Jerez y subprefecto de Écija (López Tabar, 2001: 61).

10 El Real Decreto de 31 de diciembre de 1824 reguló el Consejo de Ministros, estableciendo que la primera Secretaría de Estado y del Despacho llevara aneja la Presidencia en ausencia del rey (Gaceta de Madrid, 2, 4 de enero de 1825, p. 5).

11 Real Decreto del 5 de noviembre de 1832 mandando establecer la Secretaría de Estado y del Despacho del Fomento general del Reino (Decretos del Rey..., 17: 237). 
los reformistas de Fernando VII fue más bien la de los afrancesados, que consistía en dividir las funciones gubernativas en dos alas, reservando el nombre de policía solo para las funciones de seguridad interior (como se hizo al refundar la Superintendencia de Policía en 1824, ya para todo el Reino y no solo para la capital) e introduciendo para las restantes la denominación — también de origen francés- de Administración.

La creación de la Secretaría de Fomento respondía a la propuesta de Javier de Burgos de crear un ministerio que se encargara de la administración interior, propuesta que respaldó López Ballesteros en $1830^{12}$. Cambió varias veces de nombre en los años siguientes, llamándose Secretaría de Interior y finalmente de Gobernación ${ }^{13}$. Pero la idea fue siempre la misma: la de canalizar a través de este nuevo departamento ministerial la expansión de una Administración pública centralizada que, mediante el mecanismo expeditivo de lo gubernativo - como opuesto a lo jurisdiccional — asegurara el orden interior y fomentara las actividades productivas (de ahí los sucesivos cambios de denominación).

Fue en las obras de Burgos y Sáinz de Andino, de 1826 y 1829 respectivamente, en las que se empezó a utilizar el término administración como versión moderna del gobierno político y económico de los pueblos ${ }^{14}$. No era un mero cambio de palabra, sino expresión del paso de un conjunto de prácticas locales en manos de autoridades dotadas de jurisdicción a una nueva idea, la de Administración Pública, que materializaba la presencia de un Estado centralizado sobre todo el territorio (de ahí la mención del Reino en el nombre del ministerio, que reemplazaba a de los pueblos). Tanto Burgos como Sáinz de Andino tenían — como hemos dicho- un pasado afrancesado y miraban a Francia como modelo de referencia para sus propuestas de reforma; el texto de Javier de Burgos de 1826, con el que se abrió toda una época, incluso había

12 Minuta de una exposición dirigida a S.M. el Rey por su Ministro de Hacienda Don Luis López Ballesteros en 10 de octubre de 1830, proponiendo la creación de un Ministerio del Interior y algunas importantes mejoras de Hacienda, Archivo General de Palacio (Madrid), Papeles Reservados de Fernando VII, caja 293.

13 La Secretaría de Fomento pasó a denominarse Secretaría de Estado y del Despacho del Interior por Real Decreto de 13 de mayo de 1834 (Gaceta de Madrid, 84, 15 de mayo 1834, p. 385) y Secretaría de Gobernación del Reino por Real Decreto de 4 de diciembre de 1835 (Gaceta de Madrid, 347, 8 de diciembre 1835, p. 1386).

14 Burgos, 1834 [1826]. Pedro Sáinz de Andino: Exposición al Rey N.S. sobre la situación política del Reyno y medios de su restauración (Madrid, 1829), Biblioteca de la Universidad de Sevilla, Manuscritos, 330/166. Del texto de Sáinz de Andino hay ediciones modernas en Suárez y Berazaluze (1968), t. I, vol. 2, y en García Madaria (1982: 53-268). 
sido dirigido al rey desde París, donde su autor se hallaba comisionado por el Gobierno para resolver encargos diplomáticos y financieros. El término de administración, que estos autores fueron pioneros en proponer, constituía un galicismo, menos evidente que el ya manido y denostado de policía, definitivamente relacionado con el ejercicio de la represión para controlar el orden público, pero también procedente de Francia, pues la expresión castellana habitual para estas funciones era la de gobierno político y económico, no la de administración civil.

El nuevo concepto de administración llegaba estrechamente ligado a la difusión de la obra de Bonnin, tanto en su versión original extensa como abreviada (Bonnin, 1809, 1829). Concebida en el marco del imperio napoleónico, esta obra alcanzó una gran difusión en toda Europa, con traducciones al portugués, al alemán y al italiano. En España hubo una primera edición en 1834, aunque sin duda la obra era conocida antes en su idioma original (Bonnin, 1834). La importancia de esta obra ha llevado a considerar a su autor como el padre de lo que en la época empezó a llamarse la Ciencia de la Administración Pública (Langrod, 1957). En ella, efectivamente, se sentaron los principios que guiaron el desarrollo del Estado bonapartista sobre la base del despliegue de su burocracia. El concepto de administración sustituía al de policía que se había utilizado en la monarquía francesa del Antiguo Régimen, adaptando sus prácticas al marco de un Estado de derecho.

Bonnin fue quien primero plasmó de forma explícita el lugar que se le asignaba a la Administración en el nuevo Estado surgido de la Revolución francesa y desarrollado durante el periodo napoleónico: ese modelo de Administración densa y potente cuya expansión debía hacer realidad la construcción del Estado nacional y las promesas de modernización que este entrañaba. Por otro lado, al abogar por crear una ciencia de la Administración, lo que planteaba Bonnin era la posibilidad de sacar del debate político la mayor parte de las reformas y de las opciones administrativas, bajo la consideración de que eran materia técnica, de ciencia, que se debían dejar en manos de los expertos y no hacer depender de las ideas contrapuestas de los partidos. Esta forma de elevar los saberes administrativos a la categoría científica y situarlos por encima de las luchas políticas resultó atractiva para los conservadores españoles, y especialmente para aquellos que se dedicaban al estudio de la Administración. El argumento de Bonnin era una aplicación particular del principio más general de Auguste Comte, con quien Bonnin mantuvo una estrecha amistad desde 1829 y de quien se consideraba orgullosamente uno de los primeros discípulos (Pickering, 2009, II: 230-231). Para el fundador del positivismo, en efecto, la totalidad de las cuestiones políticas y sociales deberían quedar algún día al margen de las confrontaciones partidistas, para ser objeto de soluciones científicas incontestadas, tan pronto como madurase la nueva ciencia social 
que preconizaba y fuese ejercida por una casta sacerdotal de gobernantes científicos sin ideología. Sin llegar tan lejos, Bonnin estaba proponiendo algo parecido, al elevar la dignidad del estudio de la Administración y otorgarle la legitimidad de lo científico, camino que haría de los administrativistas los guías de la construcción del Estado y de su actuación sobre la sociedad (Flores, 1983).

La incorporación del concepto francés de Administración, así como los inicios de su implementación al servicio de un proyecto político conservador, data pues, del último periodo del reinado de Fernando VII, la llamada ominosa década (1823-1833). Aquel fue un periodo crucial en la definición de las bases del Estado español contemporáneo y en la adopción de una inspiración francesa para esa operación, que tiene por tanto una raíz autoritaria tanto o más que la relacionada con el constitucionalismo liberal. Tras la brecha abierta por los pioneros Javier de Burgos y Sáinz de Andino en tiempos de Fernando VII, la verdadera creación de una doctrina administrativista en España estuvo vinculada al auge del partido moderado - al cual pasaron ambos autores-, a partir de que conquistara el poder, primero brevemente en 1834 y 1838, y luego de forma más estable en 1843.

\section{VÍAS Y FACTORES DE CIRCULACIÓN DEL MODELO}

En 1834 se tradujo al castellano el Abregé des principes d'Administration de Bonnin (Bonnin, 1834). En 1835 (en París) y en 1838 (en Madrid) se editaron también en español los Eléments de Droit politique de Macarel, publicados en Francia cinco años antes (Macarel, 1835, 1838). No se trata, en este último caso, de una obra de derecho administrativo, pero tuvo una gran relevancia en la formación de los juristas españoles, puesto que se estuvo prescribiendo como manual universitario por orden ministerial hasta 1850 (Gallego, 2002: 158-160). La importancia de la obra, que en su traducción al español se extendía hasta referirse a la totalidad del derecho público, procedía del hecho de que exponía las instituciones - tanto políticas como administrativas- del Estado francés de Louis-Philippe con pretensiones de universalidad, como si fueran los "principios que rigen en los gobiernos constitucionales de Europa». A partir de la segunda mitad de los años treinta, pues, los juristas españoles estudiaron el derecho y el Estado - como nociones universales - a través de una obra que exponía las instituciones de Francia y su funcionamiento concreto, lo cual no podía dejar de tener consecuencias sobre las concepciones de quienes estaban llamados a participar en primera línea en la construcción del Estado a través del despliegue de su Administración. La huella explícita de aquel libro se ha 
encontrado incluso en la obra cumbre del administrativismo español, de Manuel Colmeiro (1850) (Gallego, 1982).

Para entonces, la influencia francesa penetraba ya de manera imparable, por diversas vías. Las traducciones tuvieron, sin duda, una gran incidencia: no solo las mencionadas de Bonnin y Macarel, sino también otras de menor importancia, como las de Gabriel Bourbon Leblanc en 1816 (Bourbon-Busset, 1824) y R. Gandillot en 1833 (Gandillot, 1834). La traducción de estos autores no solo apunta hacia una difusión de sus obras en España, sino que da la medida también de un conocimiento previo de las mismas por parte de una élite intelectual y profesional española que, en su mayor parte, conocía el francés y podía leer las obras en su lengua original: al apostar por traducirlas y publicarlas en España, asumían la existencia de una demanda potencial de lectores tan pronto como se abrió la transición hacia un Estado de derecho y — tal vez- la relevancia intelectual de los textos en la situación española de aquel momento.

Pero junto a estas traducciones, la circulación de personas fue otra vía de transposición de ideas y de modelos. Francisco Agustín Silvela (1803-1857) era hijo del magistrado Manuel Silvela, a quien sus compromisos con el régimen de José Bonaparte - había sido alcalde de Casa y Corte en el Madrid josefino- le obligaron a partir al exilio bajo la acusación de afrancesado con la restauración borbónica. Francisco Agustín, por tanto, se había criado y educado en Francia, donde se había licenciado en Leyes por la Universidad de París en 1833 (Pérez Núñez, 2002). Tras regresar a España fue nombrado magistrado del Tribunal Supremo y publicó su célebre Colección de Administración, que, contra lo que podría dar a entender su título meramente recopilatorio, contenía un alegato contra la pieza clave de la concepción del Estado del liberalismo progresista: la Ley para el gobierno político-económico de las provincias de $1823^{15}$, a la que Silvela llamaba «nuestra Ley administrativa por esencia» (Silvela, 1839: VII).

La Ley de 1823 constituía a los ayuntamientos y a las diputaciones provinciales en órganos representativos del vecindario y, por tanto, dotados de autonomía política y de amplias competencias administrativas. Silvela identificó que sobre esa pieza recaía todo el diseño estatal del liberalismo revolucionario y que ahí estaba la discrepancia principal con quienes, desde el Partido Moderado, se planteaban poner fin al ciclo revolucionario en España. Aquel liberalismo posrevolucionario miraba a Francia, a la Francia de la monarquía de Orléans, como modelo de estabilización para traer una política de orden al

15 Decreto XLV de las Cortes de 3 de febrero de 1823: Ley para el gobierno económicopolítico de las provincias (Colección de los decretos..., 1823, X: 171-222). 
sur de los Pirineos. Silvela reclamaba someter a los poderes locales en el marco de un Estado centralista que se sirviera de la administración directa para controlar la vida de los pueblos. Su modelo indisimulado eran las leyes de organización municipal francesas de 21 de marzo de 1831 y 18 de julio de 1837 y la Ley de consejos generales de 10 de mayo de $1838^{16}$. Más en general, su modelo de Administración era el de Francia, al que consideraba necesario recurrir por su «notable grado de perfección» (Silvela, 1839: XXXVI) y así lo mostraba al tratar prácticamente de todos los temas que debía abarcar la Administración Pública, en el sentido expansivo que se le daba en Francia: del poder ejecutivo, del gobierno municipal, las diputaciones provinciales, tribunales administrativos, gobiernos políticos, Consejo de Estado, ministerios, direcciones generales, agricultura, industria, comercio, minería, instrucción pública, policía general, sociedades económicas, imprenta, hospitales, beneficencia, cárceles, hermandades, caminos y canales, bibliotecas, museos, teatros y espectáculos, caza y pesca, estadística, división territorial... Los autores de referencia, por último, eran para él también franceses: Bonnin, Bourbon Leblanc y Gandillot (Gallego, 2001: 70-74).

La recepción del derecho administrativo francés en España se produjo en el marco de una reacción política contra la hegemonía progresista, la autonomía municipal y todo lo que representaba la Constitución de 1837. De hecho, la confrontación entre moderados y progresistas en torno a la legislación municipal, que por entonces comenzaba, continuaría — cada vez más enconada - hasta que la Ley de ayuntamientos moderada de julio de 1840 fuera contestada por el levantamiento progresista de septiembre, que llevó a la abdicación de María Cristina y a la regencia de Espartero (Castro, 1979). Tan pronto como los moderados recuperaron el poder por la fuerza en diciembre de 1843 , volvieron a poner en vigor su ley de ayuntamientos que, renovada en 1845 , se mantendría mientras estuvo vigente la Constitución de aquel año ${ }^{17}$.

Silvela había abierto un camino por el que enseguida iban a transitar otros autores, un camino cuyo trazado tenía un origen indudablemente francés. Una generación de administrativistas, vinculados todos ellos al moderantismo, fueron desarrollando la doctrina adecuada para orientar y legitimar el

16 Leyes francesas que reproduce en su Colección (Silvela, 1839: 69-79, 81-99 y 171179).

17 Ley de organización y atribuciones de los ayuntamientos, sancionada en Barcelona á 14 de Julio de 1840, y mandada publicar por S.M. en 30 de Diciembre de 1843, con las modificaciones contenidas en el Real decreto de la misma fecha (Gaceta de Madrid, 3395, 31 de diciembre 1843, pp. 1-3). Ley de organización y atribuciones de los ayuntamientos de 8 de enero de 1845 (Gaceta de Madrid, 3776, 15 de enero 1845, pp. 1-3). 
despliegue de la Administración Pública española que por aquellos años tomaba impulso. En todos ellos, la legislación municipal del trienio y sus epígonos progresistas más recientes eran atacados como una de las claves fundamentales para cambiar el modelo de Estado, junto a otras instituciones quizá más evidentes, como la Milicia Nacional, arma política del progresismo.

El libro-programa de Silvela se publicó en 1839, el mismo año en que el abrazo de Vergara selló la liquidación de la guerra en el norte, anunciando el pronto final de la primera guerra carlista, que efectivamente se produciría en 1840 con la derrota de Cabrera. Se cerraba así un largo periodo de conflictos armados y de inestabilidad política que había comenzado con la invasión francesa de la Península en 1808. Al salir de aquel ciclo de guerra y revolución, España había cambiado drásticamente de tamaño — por la pérdida de sus dominios americanos - y debía enfrentar su refundación como un Estado nacional. A esta ruptura en la concepción del poder y en la identidad de los españoles se unía el hundimiento de los aparatos administrativos de la vieja monarquía, arruinada y desorganizada hasta el extremo durante este proceso. De lo que se trataba en aquel momento era de dilucidar quién construiría el Estado nacional en España (objeto de las enconadas luchas políticas entre progresistas y moderados) y con arreglo a qué modelo lo construiría.

Los moderados ganaron aquella pugna, utilizando el modelo francés como herramienta para dar forma a su Estado administrativo y para legitimarlo. El recurso a Francia como modelo de referencia estaba relacionado con un proyecto de Estado muy concreto, que consistía en desarrollar la Administración Pública como antídoto contra la revolución. No cualquier Administración, desde luego, sino una Administración Pública centralizada al estilo francés, que llegara por sus propios medios a controlar todas las actividades políticas, económicas, sociales o culturales del país. Estos autores entendían el Estado como Administración, y la construcción del Estado nacional como el despliegue de una Administración densa, profesionalizada y numerosa, dejando en segundo plano los componentes representativos y garantistas del Estado constitucional. La mirada a Francia no era inevitable, puesto que existían alternativas que muchos políticos e intelectuales habían conocido en sus periodos de exilio, en viajes de estudios o por sus lecturas: por encima de todas, Inglaterra, que ofrecía el modelo alternativo de un Estado desarrollado como garantía de los derechos individuales, a través tanto del Parlamento como de un poder judicial efectivo e independiente. Esa alternativa, que contaba con muchos partidarios entre las filas progresistas, les parecía a todos estos autores inapropiada para el objetivo de poner orden en el país, homogeneizarlo con una autoridad central fuerte e impulsar su desarrollo económico con la intervención del Estado. Francia era el ejemplo a seguir para todo ello. 
Y esta misma opción política, que implicaba la elección de un marco de referencia predominantemente francés, suponía también una elección en cuanto al pasado español con el que se buscaba enlazar. El historicismo seguía constituyendo un elemento cultural común de los discursos políticos a derecha e izquierda de las grandes luchas políticas del momento. Todos buscaban en el pasado las fuentes de legitimación de la nación, pero en un pasado que cada uno seleccionaba y reconstruía según su criterio. Para este grupo de administrativistas cercanos al Partido Moderado, las Cortes de Cádiz y la Constitución de 1812 no formaban parte de ese pasado que había que reclamar como propio: tanto aquel episodio como la Edad Media imaginada para sustentarlo tendían a definir un modelo de Estado en gran medida jurisdiccional y parlamentario (Lorente y Garriga, 2007). La alternativa era entroncar con la tradición española por otra vía, como eran las prácticas de gobierno local de la vieja Monarquía, el llamado gobierno político y económico de los pueblos, del que se podían sacar fórmulas concretas y un estilo general de gobierno que, convenientemente adaptado, constituía un precedente adecuado para desarrollar desde arriba una Administración Pública eficaz y expeditiva (Pro, 2016b). La clave estaba en llevar a la construcción del Estado nacional una forma de gobierno basada en la autoridad de administrar y no en la elección de representantes ni en la negociación implícita en los procedimientos jurisdiccionales. Complementariamente, el discurso de apropiación de la historia española debía cambiar desde la reivindicación de las libertades castellanas y aragonesas de la Edad Media hacia la alabanza de las grandezas imperiales logradas bajo la monarquía absoluta (Cirujano, Elorriaga y Pérez Garzón, 1985; Pro, 2000).

\section{LOS ADMINISTRATIVISTAS DEL MOMENTO MODERADO}

Siguiendo la estela de Silvela, en los años cuarenta se produjo un aluvión de publicaciones sobre la Administración en España. Procedían de autores «rescatados» del Antiguo Régimen, como Burgos, Sáinz de Andino y Ortiz de Zárate, junto a otros nuevos, como Oliván, Posada Herrera y Gómez de la Serna: una pléyade de autores que culminó con Colmeiro. El momento álgido de producción doctrinal del administrativismo moderado fue el de la oposición a Espartero en 1841-1843. Hay que recordar que en 1841 aparecieron las Ideas de Administración de Javier de Burgos y un primer libro de Ortiz de Zúñiga — que se servía de las orientaciones de aquel—, al cual seguiría otro en 1842 (Ortiz de Zúñiga, 1841, 1842). En el mismo 1842 salió a la luz la primera edición del texto de Oliván (Oliván, 1843 [1842]), y en 1843 los de Posada Herrera (1843) y Gómez de la Serna (1843). 
Javier de Burgos (1778-1848), de quien ya hemos mencionado su pasado afrancesado, hubo de exiliarse en Francia por aquel motivo entre 1812 y 1819. A su regreso, y después de pasar por un expediente de "purificación", trabajó como periodista y traductor de obras francesas al español, e incluso desempeñó tareas al servicio del Gobierno antes de integrarse en la Administración de Fernando VII desde 1827. Caben pocas dudas de que su aportación al reformismo administrativo de aquellos años, encabezado por López Ballesteros, tenía que ver con su conocimiento de la experiencia francesa, con cierta brillantez intelectual para transponerla a España y con un designio de orden que le había acompañado desde que en mayo de 1810 hubiera asumido la subprefectura de Almería al servicio del Gobierno de José I (no muy distinto del que le habría inspirado ya antes, como capitán del Batallón de Milicias Honradas de Motril). Tras exponer a Fernando VII sus propuestas de reforma de la Administración — no por casualidad desde París, en 1826-, acabó siendo secretario de Estado de Fomento en el primer Gobierno de María Cristina y firmó la decisiva división provincial de 1833 (Gay, 1993).

Esta disposición puso los fundamentos para crear en España una Administración pública moderna, racionalizando la estructura territorial del Estado para un largo periodo de tiempo. Se venía preparando al menos desde la creación de una comisión ministerial en 1825 y contaba con antecedentes muy importantes - que en parte convenía no imitar, por razones simbólicascomo la división de España en prefecturas por el Gobierno afrancesado (1810) y la división provincial de los constitucionales (1822) (Burgueño, 1996). Directamente o a través de los trabajos previos, la división de 1833 se inspiraba en la división de Francia en departamentos por la Revolución (1790); y la figura que entonces se creó de los subdelegados de Fomento, antecedentes directos de los gobernadores provinciales que Burgos había propuesto ya desde la exposición de 1826, también venía en principio de los prefectos franceses. No obstante, son muy grandes las diferencias entre el modelo original francés, más revolucionario y estrictamente racionalista, y su aplicación en España, más respetuosa de tradiciones históricas como las de los reinos preexistentes en la monarquía (Pérez Núñez, 1998, 2011). Y esta diferencia nos da una medida de la manera en que se produjo la apropiación en España del modelo francés: mediando una simplificación de los matices presentes en el caso que se tomaba como ejemplo, una adaptación a las circunstancias del país de destino y una instrumentalización al servicio de un proyecto político, proyecto que, en el caso de España, no era el de una ruptura revolucionaria con el pasado, sino simplemente el de una mejora en la eficacia del control que el poder central ejercía sobre el territorio.

Tras aquel importante servicio a la construcción del Estado desde un Gobierno aún neoabsolutista como el que encabezó Cea Bermúdez, Javier de 
Burgos permaneció cercano a las posturas monárquicas más conservadoras y se integró en el Partido Moderado. Formó parte del Estamento de Próceres del Estatuto Real (1834-1836), fue nombrado senador vitalicio (1845) y ministro de Gobernación, ya en la década moderada, con Narváez como presidente (1846). Toda esta relevancia que se le concedía está en relación con su papel orientador de la construcción del Estado, manifiesto en tres textos fundamentales: la ya citada Exposición de 1826, la Instrucción a los subdelegados de Fomento de 1833 y sus Ideas de Administración de 1841. Estas últimas procedían de una serie de conferencias pronunciadas en el Liceo de Granada y publicadas después en el periódico La Alhambra de aquella ciudad. En ellas, además de esbozar un modelo administrativo calcado del francés, se defendía que esa Administración Pública poderosa era necesaria —entre otras cosaspara proteger a la industria nacional de la competencia extranjera hasta el momento en que tuviera fuerza suficiente para competir en un mercado libre (Burgos y Roca, 1987 [1841]). Era el argumento del nacionalismo económico que en aquel mismo año sistematizó List en Alemania, argumento que alejaba definitivamente a Burgos - y con él al programa de los moderados españoles- del modelo británico.

Manuel Ortiz de Zúñiga (1806-1874), otro de los autores de referencia del administrativismo conservador isabelino, no tenía un pasado afrancesado ni de exilio en Francia. Su primera obra en este terreno tenía más que ver con la traslación a la modernidad de las prácticas locales del gobierno político y económico de los pueblos del Antiguo Régimen que con la observación de modelos extranjeros (Ortiz de Zúñiga, 1832). Pero en sus obras posteriores encontramos detalles que muestran la preponderancia del grupo afrancesado en el administrativismo del gran momento moderado de 1841-1843. En la obra de 1842 retomaba los trabajos de Silvela y Oliván, se apoyaba en Javier de Burgos, al que citaba ampliamente, $y$, como tantos otros autores de aquel grupo, apelaba a la autoridad de autores franceses como Gérando, Macarel, Fleurigeon, Émile-Victor-Masséna Foucart, Claude-Joseph Lalouette, Albin Lerat de Magnitot y Huard Delamarre, siendo visible la influencia de Bonnin (Ortiz de Zúñiga, 1842).

Alejandro Oliván (1796-1878) fue más allá que sus predecesores, al plasmar en su obra íntegramente un modelo de Estado grande que habría de materializarse en una Administración profesional perfectamente jerarquizada y centralizada, que supervisara mediante departamentos especializados de funcionarios la totalidad de las actividades del país (Pro, 2016b). Oliván se había educado en Francia desde niño, no por razón de exilios familiares ni de circunstancias políticas, sino porque en la región del Alto Aragón, donde nació, era esta una opción frecuente entre las familias acomodadas. Tras su formación en un internado de Sorèze —en plena época napoleónica— volvió 
a Francia varias veces, ahora ya sí como refugiado: la primera en 1823, tras la segunda restauración absolutista; la segunda en 1836, tras el movimiento revolucionario progresista de aquel verano; y la tercera en 1840, también como consecuencia del acceso al poder de los progresistas. Tenía un excelente conocimiento de la realidad francesa y una marcada francofilia, que le hacía mirar hacia los asuntos de aquel país con admiración y tener una visión muy francesa sobre los propios asuntos españoles (Martín-Retortillo, 1997).

En Oliván encontramos de manera explícita la esencia del afrancesamiento que en otros autores permanece más bien implícita: la voluntad de llevar a España al punto en el que Francia se encontraba ya, sin pasar por sus experiencias históricas previas, esto es, fundamentalmente, ahorrándole la Revolución:

En esa Francia, cuyas vicisitudes son un libro abierto a las naciones que busquen la experiencia sin pasar por los duros trances que cuesta el adquirirla por sí, todos los gobiernos que se han sucedido en el espacio de cuarenta años, han puesto en armonía con su propia esencia y estructura las formas administrativas del país (Oliván, 1843 [1842]: 23-24).

Su francofilia era, quizá, la más nítida, llegando a defender el centralismo como modelo superior de administración con la comparación de la experiencia de Francia respecto a la de Gran Bretaña. Según Oliván, el papel que en el sistema británico se dejaba a los poderes locales y a la iniciativa privada determinaba fracasos memorables y una menor eficacia en general (Oliván, 1843 [1842]: 25-27).

Oliván había iniciado una carrera militar y científica, que cambió en 1836 por la dedicación prioritaria a la política y la Administración. Se le confirieron multitud de cargos burocráticos en los que se fue fraguando un perfil técnico, de especialista en las arduas tareas de formación de las instituciones del Estado naciente. Fue varias veces diputado (de 1837 a 1851), senador (desde 1851) y subsecretario de Gobernación, una vez ministro (de Marina, en 1847) y vocal o presidente de innumerables comisiones: el Consejo de Agricultura, Industria y Comercio, el Consejo de Instrucción Pública, la Junta consultiva de Monedas, la Comisión de Pesas y Medidas, la Junta central de Estadística, la Junta directiva de la Deuda... Lidió, por tanto, con operaciones como los censos de población, el catastro de la riqueza rústica y urbana, la ley de aguas, el arreglo de la deuda pública, la unificación monetaria o la introducción del sistema métrico decimal, en todas las cuales aplicó su idea de la Administración Pública de matriz francesa.

Desde el punto de vista doctrinal, su obra De la Administración pública en relación a España puede ser leída como un esbozo utópico de los límites hasta los que se podía llevar la idea de los moderados de construir en España 
ese Estado grande con una administración numerosa y presente en todas partes. Aquel desarrollo de la idea común de los administrativistas sería el que mejor realizaría la pretensión, típicamente francesa, de conceder al Estado un papel preponderante en la organización de la vida social.

\section{DEL MODELO FRANCÉS A LA REALIDAD ESPAÑOLA}

En la práctica, la apuesta que hemos visto en autores como Silvela u Oliván por el modelo francés de la tradición jacobina, dispuesto a barrer toda clase de cuerpos intermedios y a hacer del Estado - materializado en su Administración - el único representante legítimo de la colectividad, para reconstruir completamente la realidad del país mediante la Ley y la acción administrativa, tenía mucho de irreal en las circunstancias españolas del momento. Funcionó como un marcador de rumbo para definir a grandes rasgos la Administración Pública española durante la década moderada (18441854), pero no se daban las condiciones para llevar el modelo hasta sus últimas consecuencias. La relación de fuerzas entre el poder central y los poderes locales era radicalmente distinta que en Francia, y requería mucho más de pactos y negociaciones (Martí y Romeo, 2006; Calatayud, Millán y Romeo, 2009).

Aunque el libro de Oliván funcionara como símbolo de las aspiraciones máximas del moderantismo en cuanto a la construcción del Estado, la solución por la que transitó en la práctica aquel proceso se pareció mucho más a la que había esbozado Ortiz de Zúñiga. Frente al Estado fuerte que se hace presente en la vida social mediante su propia Administración centralizada, Ortiz había vislumbrado la idea de convertir a los ayuntamientos en auxiliares administrativos del Gobierno, aunque eliminando de los mismos toda autonomía política para someterlos a los dictados del centro. Este sucedáneo de Estado centralizado resultaba factible porque en la práctica era como ya estaba funcionando la Administración española, sirviéndose de las corporaciones locales para llegar hasta los rincones del territorio donde no podía llegar por sí misma debido a la escasez de funcionarios, de recursos económicos y de comunicaciones eficientes (Pro, 2016a). Manteniendo, pues, la ficción del Estado unitario y el gobierno centralizado, la práctica administrativa tenía mucho más de confederación de municipios y de negociación permanente con las oligarquías que los gobernaban. Fue así como los moderados desvirtuaron el modelo francés en el que se habían inspirado originalmente, incorporando partes del mismo en la formulación concreta de las instituciones y en la definición teórica del Estado, pero sirviéndose de una estructura general de facto diferente, adaptada a las circunstancias que caracterizaban a España al término de la primera guerra carlista (1840). 
La labor iniciada en el plano doctrinal entre 1839 y 1843 culminó en 1845 con la Constitución que impusieron unilateralmente los moderados, corrigiendo la de 1837 en un sentido más monárquico, autoritario y centralista (Marcuello, 2007). La Constitución venía acompañada de normas tan importantes como la Ley de ayuntamientos, que afianzó la doctrina moderada que convertía a los entes locales en agentes administrativos del Gobierno, sin vida política propia. En la propia Constitución se realizó otro cambio de gran envergadura, como fue la sustitución del concepto de poder judicial, que aparecía en el título 10 de la Constitución de 1837, por el de administración de justicia (tít. X de la Constitución de 1845). El cambio no era solo terminológico, sino que reflejaba la renuncia a considerar a la justicia como un poder independiente del Estado, sometiéndola a la lógica gubernativa de la administración, como un departamento más de la misma. Al hacer esto, se confinaba a los jueces y tribunales a una función específica, supervisada desde el Gobierno, y se liberaba a la Administración de todo control judicial (Solla, 2007).

No es casualidad que en el mismo año 1845 se regulara en España la jurisdicción contencioso administrativa, pieza clave del nuevo Estado, que convertía a la Administración en juez y parte de los posibles conflictos en los que incurriera con los ciudadanos ${ }^{18}$. De este modo, se apartaba a los jueces y tribunales de la defensa de los derechos constitucionales frente a la Administración, dando un salto de gigante hacia el modelo de gobierno expeditivo y unilateral que iba implícito en la expansión de la lógica de lo administrativo. Este tipo de justicia, privada de independencia y sometida a la Administración, procedía también de Francia y era uno de los componentes básicos de su específico modelo de Estado. Era la herencia de la obra revolucionaria de 1790, pasada por el tamiz de las reformas napoleónicas, cuando empezó a instalarse en España en los años treinta y cuarenta del siglo xix (Clavero, 2007: 410).

La intención política - y selectiva - de las apelaciones al modelo francés resulta evidente; pero también lo es que cuando aquel modelo no encajaba con los intereses del moderantismo, se corregía o se abandonaba en lo que fuese necesario, aludiendo a la diferencia en las circunstancias de los dos países. Un ejemplo claro puede ser el de la Hacienda pública, y en particular sus instrumentos para distribuir la carga tributaria. Después de muchos intentos fallidos para reemplazar la anquilosada Hacienda Real del Antiguo Régimen

18 Ley de 2 de abril de 1845 sobre organización y atribuciones de los consejos provinciales (Gaceta de Madrid, 3860, 9 de abril 1845, pp. 1-2); Ley de 6 de julio de 1845 que resuelve la organización y atribuciones del Consejo supremo de Administración del Estado (Consejo Real) (Gaceta de Madrid, 3955, 13 de julio 1845, p. 1). 
(desde 1810 hasta 1842), la llamada reforma de Mon de 1845 hizo realidad un nuevo sistema tributario, más ajustado a los principios constitucionales y a las necesidades del siglo $\mathrm{XIX}^{19}$. El modelo fueron los impuestos de producto que en Francia había creado la Revolución, y especialmente uno de ellos, el que gravaba las actividades agrícolas y la propiedad de la tierra: la Contribution foncière francesa de 1790 fue transformada en la Contribución de Inmuebles, Cultivo y Ganadería española (Fuentes Quintana, 1978).

Sin embargo, el sistema no fue completado con su pieza fundamental, que era el levantamiento de un catastro para conocer el reparto de la propiedad y hacer equitativas las cotas de la contribución correspondiente. Aquello habría significado que la carga cayera sobre los grandes propietarios en proporción a su riqueza, los mismos propietarios que debían proporcionar la base social del régimen moderado. Para evitarlo, se argumentó que el catastro había sido un fracaso en Francia y que constituía una obra demasiado costosa para las posibilidades económicas de un país más pobre, como era España. Con esa justificación, se desvirtuó el sistema tributario francés, orientado a garantizar la proporcionalidad en el pago de los impuestos directos como manifestación fiscal de la igualdad ante la ley de todos los ciudadanos. Y en lugar de levantar un catastro riguroso por parte del Estado, una Comisión especial de Hacienda presidida por Javier de Burgos optó por el sistema de cupos territoriales; es decir, un reparto del impuesto entre las provincias, y de estas a los municipios, dejando que en cada pueblo o ciudad fueran los poderes locales quienes repartieran la carga entre los vecinos. Para hacerlo, estos poderes de composición oligárquica elaborarían unas listas de propiedades sin medición objetiva ni valoración técnica, llamadas primero padrones de la riqueza y luego, desde 1850, amillaramientos. Los grandes propietarios y los poderosos locales adquirieron así la capacidad de eludir la carga fiscal que les correspondía y repartirla según una lógica clientelar que perjudicaba a los menos influyentes (Pro, 1992, 1994, 1996; Vallejo, 2001).

El mecanismo permaneció vigente durante toda la segunda mitad del siglo XIX, y en algunas zonas de España hasta bien entrado el siglo xx. Era un mecanismo muy representativo del funcionamiento de hecho del nuevo Estado, en el que gran parte de las actuaciones administrativas descansaban sobre unos ayuntamientos de constitución oligárquica, pero sin vida política propia. En el caso de la tributación, la peculiar adaptación que consistía en copiar el impuesto francés, pero sin el catastro que permitía repartirlo de

19 Ley de 23 de mayo de 1845 de presupuesto general de gastos e ingresos del Estado (Gaceta de Madrid, 3925, 13 de junio 1845, pp. 1-2; 3926, 14 de junio, pp. 1-3; 3927, 15 de junio, pp. 1-3 y 3928, 16 de junio, pp. 1-3). 
manera equitativa, significó la pervivencia de una ocultación fiscal masiva, una distribución de la carga marcadamente regresiva y una limitación de la capacidad recaudatoria de la Hacienda pública, en beneficio de los grandes propietarios atrincherados en el poder municipal y en detrimento de las posibilidades financieras de actuación del Estado en todos los terrenos. Modelo francés sí, pues, pero desvinculado de sus raíces revolucionarias y puesto al servicio del mantenimiento de un orden social y político que los moderados no deseaban poner en peligro.

\section{LA MADUREZ DEL SISTEMA Y SUS MATIZACIONES}

Los avances del administrativismo moderado en los años cuarenta culminaron al final de aquel decenio con la publicación del Derecho administrativo español de Manuel Colmeiro, autor con quien también culminó la institucionalización del administrativismo en España (Colmeiro, 1850). En 1847 ganó la cátedra de Derecho Político y Administración en la Universidad Central de Madrid (que desempeñó hasta 1881). Y tres años después publicaba aquel manual para la enseñanza del Derecho Administrativo, que sería la obra de referencia en su materia.

Puesto que el Derecho Administrativo no se codificó, siguiendo el precedente de Francia, los manuales vinieron a desempeñar la función del código inexistente, proporcionando una visión de conjunto del derecho vigente en ese campo. Y entre los manuales, los de Colmeiro fueron los más exitosos durante toda la segunda mitad del XIX, hasta que vinieron a ser reemplazados por los de Vicente Santamaría de Paredes, ya en las últimas décadas del siglo ${ }^{20}$. Aunque la parte creativa y sistematizadora corresponde a los autores anteriores, Colmeiro tiene, pues, ese valor de suma madura de un derecho ya no proyectado, sino en vigor. Al igual que sus predecesores en España - a todos los cuales cita abundantemente-, los franceses están también en la obra de Colmeiro: Montesquieu, Bonnin, Macarel, Gerando, Foucart, Alphonse Bérenger de la Drôme, Tanneguy Duchâtel, Auguste Vivien, Henrion de Pansey, el vizconde de Cormenin (Louis-Marie de Lahaye)... Con la diferencia de que esta vez las calidades del autor español fueron tales que, por primera vez, se invirtió la tendencia en la circulación de escritos sobre la Administración Pública, llegando a ser citado de manera elogiosa por franceses como Anselme Batbie y Edouard

20 Hablamos de ellos en plural, porque fueron dos los manuales de Colmeiro: el grande (Colmeiro, 1850) y el chico (Colmeiro, 1858) y también fueron dos los de Santamaría de Paredes $(1881,1885)$. 
Laferrière (Batbie, 1861-1868, I: 8; Laferrière, 1887-1888, I: 27-34). Este último declaró haberse inspirado en la obra de Colmeiro no solo por las noticias que daba de España sino por su método general (Nieto, 1965: 59).

Como síntesis del modelo de Estado que habían perseguido los moderados, encontramos descrita nítidamente en Colmeiro la preeminencia del Estado sobre la sociedad y de la Administración sobre cualquier otro componente del Estado. Para Colmeiro, «el gobierno es la personificación del estado», dado que «posee la plenitud de las funciones propias del único poder social existente: dicta la ley, declara el derecho y provee al bien común, o legisla, juzga y administra» (Colmeiro, 1850, I: 5). Ese Estado es fundamentalmente Administración y se rige por una lógica administrativa en todas sus funciones e instituciones ("Administrar, pues, equivale a gobernar; es decir, ejercer el poder ejecutivo»). Las funciones y facultades del Estado son las de la Administración, y las describe con extensión comparable a la que le había dado Oliván, como un aparato omnipresente en la vida social, económica y política del país:

Nada hay indiferente para la administración desde lo más grande hasta lo más pequeño; o por mejor decir, nada parece pequeño a los ojos de una administración solícita por el bien del estado; porque las cosas mínimas en la vida privada adquieren gigantescas proporciones en la existencia social; de que se infiere que su mirada debe ser penetrante, su voluntad firme, permanente su acción y su perseverancia infatigable (Colmeiro, 1850, I: 8).

Al explicar el sentido de la jurisdicción contencioso-administrativa, en el libro quinto, Colmeiro justifica la necesidad de que los actos administrativos no se sometan a la jurisdicción ordinaria de jueces y tribunales, para evitar que estos fiscalicen a la Administración y, por ese medio, pudieran poner límites a la arbitrariedad del Gobierno (Colmeiro, 1850, II: 217-298). El ideal que trajera de Francia Silvela once años antes estaba ya plenamente realizado sobre el papel: plasmado en una nueva Constitución y nuevas leyes que la desarrollaban, y sustentado por una doctrina madura que no tenía apenas contestación. Sabemos, no obstante, que el sistema real no era el mismo que describían estos textos y que, por tanto, estos seguían funcionando como un modelo ideal que legitimaba el orden establecido, apelando al prestigio de que era así como se hacían las cosas en la admirada Francia.

Lógicamente, no existió una total unanimidad entre los administrativistas españoles de aquel momento (como no había existido tampoco entre los franceses). Algunos matices pueden establecerse entre las propuestas de los diferentes autores. Por ejemplo, José Posada Herrera asumió en sus Lecciones de Administración posiciones más centradas, reivindicando las virtudes de la Instrucción de 1823 y la posibilidad de conservar un cierto grado de autonomía local en el 
marco del nuevo Estado (Posada Herrera, 1843). No es extraño que esta postura viniera de un jurista procedente del partido progresista y que por entonces se pasaba a las filas moderadas, antes de integrarse, a partir de 1858, en la opción centrista que representaba la Unión Liberal. Tampoco parece casualidad que este administrativista políticamente ubicuo, que discrepaba en aspectos importantes del modelo de Estado de los moderados más «puros», fuera el que menos referencia hiciera al modelo francés y el que menos se apoyara en autores de aquel país, llegando incluso a criticar a Bonnin. Aun así, cita tanto a Bonnin como a Macarel, Condillot, Alexis de Tocqueville, Cormenin, Henrion de Pansey, Adolphe Trebuchet, Maurice Mejan, etc.

En todo caso, el tipo de Administración que materializaría la construcción del Estado nacional era en la obra de Posada Herrera tan ambicioso como en las de Oliván o Burgos: una Administración con funciones económicas (pesas y medidas, moneda, bancos, comercio, aduanas, mercados, obras públicas, caminos, canales, minas, aguas, propiedad del suelo, patentes...), funciones morales (instrucción pública, imprenta, policía urbana, higiene, beneficencia, casas de corrección...) y funciones tutelares (sobre la infancia, por ejemplo). No se trataría, pues, de un Estado mínimo como el que soñara la economía política clásica británica, sino de un Estado nacionalizador y grande, inspirado por el ideal jacobino, aunque fuera al servicio de principios conservadores y no revolucionarios.

Otra matización hay que señalar: la influencia alemana en esta corriente administrativista no fue desdeñable. Pero dos precisiones hacen que la influencia alemana observable no contradiga el predominio de la francesa: por un lado, por razones de proximidad, de conocimiento del idioma y de vínculos históricos y culturales seculares, gran parte de los elementos que se tomaban de Alemania llegaban a través de su previa aclimatación en Francia, como si fueran novedades francesas. Un ejemplo podría ser el sistema de formación en Ciencia de la Administración o Ciencia política separada del Derecho, algo que procedía de las universidades alemanas y que fue llevado a Francia por autores franceses como Georges Cuvier, Edouard de Laboulaye, Louis Wolowski, Charles Vergé o August Vivien durante la Restauración borbónica y la Monarquía de Julio (Osborne, 1989). La tendencia que por un momento hubo en España a instalar en las facultades de Filosofía y Letras - y no en las de Derecho- la enseñanza de la Ciencia de la Administración respondía a ese influjo, y también la creación, en 1842, de la Escuela especial de Administración $^{21}$.

21 Real Decreto de 29 de diciembre de 1842 por el que se establece en Madrid una Escuela especial de Administración (Gaceta de Madrid, 3009, 2 de enero de 1843, p. 2). 
La otra precisión importante que hay que hacer con respecto a la influencia alemana es que ganó importancia a medida que fue avanzando el siglo y sobre todo después de la unificación de Alemania en 1870. Para entonces el administrativismo español ya estaba formado e institucionalizado - sobre bases francesas - y había pasado el momento de mayor influencia sobre la construcción de las instituciones del Estado-nación. Esa influencia alemana, que consistía fundamentalmente en incorporar el método jurídico para superar las exposiciones meramente descriptivas de los decenios centrales del XIX, es visible en manuales como el de Gascón (1917)22. En los últimos decenios del xix y los primeros del xx, la vieja Ciencia de la Administración hispana, que reciclaba materiales franceses, se transformó en verdadero derecho administrativo que pasaba por aplicar a una Administración Pública ya formada en su mayor parte una técnica jurídica procedente de autores alemanes como Otto Mayer o Paul Laband (Gallego, 2002: 54).

Por otra parte, la apropiación de lo francés fue selectiva, crítica e instrumental, no una mera imitación. Algunos autores lo señalaron de manera explícita: Ortiz de Zúñiga indicó al referirse a los grandes autores franceses de referencia que había que tener cuidado de "no dejarse deslumbrar con teorías de difícil aplicación a España y a nuestra situación actual» (Ortiz de Zúñiga, 1842: XI). Algo parecido a lo que quería señalar Posada Herrera al advertir que la atención al modelo francés no debía llevar a «abandonar nuestros usos, nuestras costumbres, para adoptar los usos y costumbres extrañas» (Posada Herrera, 1843: 202); pero es que incluso el más francés de los administrativistas moderados, Silvela, fue también claro en este punto:

Presentar el cuadro de la administración francesa no es pretender que se adopte absolutamente el sistema (y sobre esto hacemos formal protesta), sin atender a lo que pueda haber de singular en nuestras necesidades, usos y costumbres. Además de que, lo que es bueno en sí, no es francés, ni español, ni ruso: es de todas las naciones y de todas las edades (Silvela, 1839: XXXVI).

Con las matizaciones apuntadas, el desarrollo del administrativismo conservador de raíz francesa fue espectacular durante los años de hegemonía política del partido moderado bajo el reinado de Isabel II. Avanzada aquella época, el éxito se plasmó en la aparición de una carrera universitaria específica de Derecho administrativo en 1857, con títulos de bachiller, licenciado y doctor. Fuera ya del periodo de estudio aquí acotado, que se limita al reinado de Isabel II, la idea de Estado de aquellos administrativistas moderados tuvo un

22 De este libro se hicieron hasta 13 ediciones, la última en 1955. 
largo recorrido, puesto que las grandes líneas que habían trazado para el desarrollo de la Administración Pública serían visibles hasta la crisis de la Restauración, cuando no hasta el franquismo. De hecho, cuando ya en la Restauración dejaron de usarse en la enseñanza universitaria del derecho las obras de referencia del administrativismo moderado, y especialmente la de Colmeiro, fue para sustituirlas por obras como las de Santamaría de Paredes, quien seguía realzando el papel de la Administración como encargada de cumplir los fines del Estado (Santamaría de Paredes, 1881: 42).

\section{UN BALANCE DE LA REAPROPIACIÓN DEL MODELO FRANCÉS}

La fuerte impronta francesa en el modelo de Administración y de Estado que perseguían los moderados ha sido reconocida por una amplia historiografía $^{23}$. El alcance de esa filiación ha sido oscurecido en ocasiones por el afán patriótico de los autores de la época - y de algunos comentaristas y estudiosos actuales-, que han subrayado la originalidad de las instituciones españolas por la vía de magnificar las diferencias que se pueden sin duda señalar entre el original y la copia. Ciertamente, la apropiación del modelo francés no devino en una traslación literal del mismo, sino en su instrumentalización al servicio de un proyecto político posrevolucionario, lo cual requería multitud de adaptaciones y correcciones. Los administrativistas españoles rechazaban el seguidismo de lo francés que identificaban con la Constitución de 1812 y el periodo en que estuvo vigente, pasando por alto que a pesar de la comparación que se pueda hacer con la francesa de 1791, aquella fue la menos francesa de las constituciones españolas del $\mathrm{XIX}^{24}$. La crítica al tipo de Estado que se encuentra en la Constitución de 1812 y en la Ley de 1823 la hacían estos administrativistas en nombre de principios y doctrinas que tomaban fundamentalmente de Francia, de la Francia posrevolucionaria.

El Estado francés que se tomaba como modelo era el de la Monarquía de Julio, resultado final de un conjunto de transformaciones realizadas sobre la Administración fundada y desarrollada en el periodo napoleónico. La clave de aquel modelo era el anclaje de la Administración en el poder ejecutivo, que nombraba y separaba a los empleados públicos, dictaba los reglamentos y organizaba a los funcionarios en cuerpos y carreras (Fuentetaja, 2013: 38-42).

23 Pueden señalarse como ejemplos de esta historiografía las obras de Santamaría (1973) y Nieto (1996), entre otras.

24 Por ejemplo, Javier de Burgos al final de las conferencias de Granada de 1841, en Burgos y Roca (1987 [1841]). 
Un cierto sentido militar latía detrás de la jerarquización y disciplina de estos cuerpos civiles, e incluso detrás del mecanismo de ocupación del territorio, con unos prefectos que debían asegurar la paz en sus departamentos y dirigir el despliegue en los mismos de la acción administrativa. El sistema se apoyaba en la protección de la Administración frente a los jueces y tribunales, establecida ya en época revolucionaria como principio, al prohibir a los jueces interferir en la acción de los funcionarios públicos para defender derechos fundamentales de los ciudadanos ${ }^{25}$. La Constitución napoleónica del año viII (1799) perfeccionó este sistema creando el Consejo de Estado, en el que radicaba una jurisdicción especial controlada por la propia Administración para resolver este tipo de conflictos. Tras la revolución de 1830, el modelo se llevó hasta sus últimas consecuencias con el sometimiento completo de los municipios y de los consejos departamentales a los todopoderosos prefectos en las leyes de 1831, 1837 y 1838.

Lo que se buscaba al tomar a Francia como modelo de referencia era dar un giro político al curso que los progresistas habían impuesto a la construcción del Estado nacional desde la entrada en vigor de la Constitución de 1837. Un giro que asegurara de forma efectiva la tutela de la Corona sobre el conjunto del sistema político a través de un poder ejecutivo todopoderoso, un Gobierno central dotado de una Administración pública jerarquizada que, mediante una cadena de mando que pasara por los gobernadores provinciales y llegara hasta los ayuntamientos, hiciera de estos dependencias administrativas funcionales en el nivel local. Las doctrinas francesas, legitimadas por la existencia de una supuesta Ciencia de la Administración, hablaban de la superioridad del modelo centralista, la necesidad de privar de toda autonomía política a las corporaciones locales, la protección de la Administración frente a la intromisión de los jueces... en fin, de elementos que, debidamente reconstruidos en un país diferente y con menos recursos humanos y materiales, podría dar el resultado apetecido de poner fin al ciclo revolucionario, apartar las disidencias políticas y el autogobierno municipal, y lograr una nación uniforme controlada desde arriba por un régimen político que - dicho sea de paso- se hacía al mismo tiempo poco representativo y marcadamente autoritario.

La apelación de los administrativistas a fuentes y autores franceses tenía, fundamentalmente, una función de legitimación para este giro político. Pero para que ese efecto legitimador funcionara, la Ciencia de la Administración tenía que ser elevada a la categoría de mito, casi sacralizada. Contando con que muy pocos leerían las obras originales de los autores franceses a los cuales se aludía, bastaba con citarlos y esperar que el prestigio de su origen francés y

25 Constitución francesa de 1791, tít. III, cap. V, art. 3. 
su supuesto carácter científico hicieran el resto. No obstante, hoy resulta obvio, de entrada, que aquellas obras no tenían nada de ciencia: se propugnaban las virtudes de un modo concreto de organización de las instituciones porque protegían y desarrollaban determinados valores cuyo sentido político se hurtaba al profano. Ninguna investigación, ninguna discusión profunda, ninguna experimentación, ninguna contrastación histórica sustentaba las afirmaciones de los autores que se citaban como autoridades científicas. Lo que se encuentra en todos ellos (Bonnin, Macarel, Gandillot...) es la descripción de un modelo - el de Francia - elevado a la categoría de universal, tras dar por hecha su superioridad.

Sabemos que la alusión continua a los autores franceses tenía esa función de legitimación de un giro político de largo alcance en los años cuarenta porque, tan pronto como ese giro estuvo iniciado y la construcción del Estado tomó el rumbo que los moderados pretendían, empezaron a ser menos frecuentes tales citas. Aunque el administrativismo español siguió inspirándose fundamentalmente en doctrinas francesas hasta la época de la Restauración, esa filiación se hizo menos explícita con el tiempo, y, sobre todo, dejó de insistirse en el valor científico de las propuestas que se hacían en materia de Administración Pública y de atribuir a la Administración cualidades mesiánicas para la felicidad de la nación. Una vez consolidado el modelo moderado, las alusiones a la doctrina francesa empezaron a resultar innecesarias, e incluso podían constituir una carga. En la obra con la que culminó el administrativismo español del siglo xIx, el Derecho administrativo español de Colmeiro (1850), habían desaparecido las apelaciones a una Ciencia de la Administración y el papel legitimador de la doctrina francesa era ya mucho más discreto, aunque la inspiración del modelo administrativo francés siguiera siendo palpable en su descripción de la normativa española vigente (Gallego Anabitarte, 2002: 248-253).

\section{Bibliografía}

Batbie, A. (1861-1868). Traité théorique et pratique de droit public et administratif. Paris: Cotillon, 7 vols.

Bonnin, Ch. J. B. (1809). Principes d'administration publique pour servir à l'étude des lois administratives suivies du projet de ce code: et considérations sur l'importance et la nécessité d'un code administratif. Paris: Clament frères, $2^{\mathrm{a}}$ ed.

- (1829). Abrégé des "Principes d'administration». Paris: Amable-Costes.

— (1834). Compendio de los principios de Administracion. Madrid: Imprenta de José Palacios, traducido por D. J. M. Saavedra.

Bourbon-Busset, G. de (1824). Filosofía política. Madrid: Imp. de Miguel de Burgos.

Burgos, J. de (1834 [1826]). Exposicion dirigida á S.M. el Sr. D. Fernando VII desde Paris en 24 de enero de 1826... sobre los males que aquejaban á España en aquella época, y medidas que debía adoptar el gobierno para remediarlos. Cádiz: Imprenta de Ana Benítez. 
Burgos, J. de y Roca, E. (1987 [1841]). Las ideas de administración de Javier de Burgos. Madrid: Instituto Nacional de Administración Pública.

Burgueño, J. (1996). Geografía política de la España constitucional: La división provincial. Madrid: Centro de Estudios Constitucionales.

Calatayud, S., Millán, J. y Romeo, M. C. (2009). El Estado en la configuración de la España contemporánea. Una revisión de los problemas historiográficos. En S. Calatayud, J. Millán y M. C. Romeo (eds.). Estado y periferias en la España del siglo XIX (pp. 9-130). Valencia: Publicacions de la Universitat de València.

Castro, C. de (1979). La revolución liberal y los municipios españoles (1812-1868). Madrid: Alianza Editorial.

Cirujano Marín, P., Elorriaga Planes, T. y Pérez Garzón, J. S. (1985). Historiografía y nacionalismo español (1834-1868). Madrid: CSIC.

Clavero, B. (2007). Justicia en España entre historia y Constitución, historias y constituciones. En De justicia de jueces a justicia de leyes: hacia la España de 1870 (pp. 399-428). Madrid: Consejo General del Poder Judicial.

Colección de los decretos y órdenes que han expedido las Córtes Generales y Extraordinarias. Madrid: Imprenta Nacional, 1820-1823, 10 vols.

Colmeiro, M. (1850). Derecho administrativo español. Madrid-Santiago-Lima: Calleja, 2 vols.

- (1858). Elementos del derecho politico y administrativo de España. Madrid-Santiago-Valparaíso-Lima: Calleja.

Decretos del Rey Nuestro Señor Don Fernando VII, y Reales Ordenes, Resoluciones y Reglamentos Generales expedidos por las Secretarias del Despacho Universal y Consejos de S.M.. Madrid: Imprenta Real, 1824-1834, 11 vols. (vols. 8 a 18 de la Colección Legislativa).

Dou y de Bassols, R. L. de (1800-1803). Instituciones del derecho público general de España con noticia del particular de Cataluña y de las principales reglas de gobierno en cualquier Estado. Madrid: Benito García, 9 vols.

Flores Cruz, C. (1983). Bonnin y la ciencia administrativa. Revista de Administración Pública (México), 54, 547-556.

Fuentes Quintana, E. (1978). El estilo tributario latino: características principales y problemas de su reforma. En Ciencia social y análisis económico. Estudios en homenaje a Valentín Andrés Álvarez (pp. 195-279). Madrid: Tecnos.

Fuentetaja Pastor, J. Á. (2013). Pasado, presente y futuro de la función pública: entre la politización y la patrimonialización. Madrid: Civitas.

Gallego Anabitarte, A. (1982). Los cuadros del Museo del Prado (I): Reflexiones histórico y dogmático-jurídicas con ocasión del artículo 132 (y 133.1) de la Constitución española de 1978. En Administración y Constitución: estudios en homenaje al profesor Mesa Moles (pp. 227-310). Madrid: Presidencia del Gobierno.

- (2001). Influencias nacionales y foráneas en la creación del Derecho administrativo español. En Posada Herrera y los orígenes del derecho administrativo español (pp. 31-76). Madrid: Instituto Nacional de Administración Pública.

- (2002). Formación y enseñanza del Derecho público en España (1769-2000). Un ensayo critico. Madrid: Marcial Pons.

Gandillot, R. (1834). Curso de derecho administrativo. Madrid: José Espinosa. 
García Madaria, J. M. (ed.) (1982). El pensamiento administrativo de P. Sáinz de Andino. Madrid: Instituto Nacional de Administración Pública.

García Monerris, C. y E. (2008). «Civilidad» y «Buen gobierno»: la «Policía» en el siglo XvıII. Saitabi, 58, 393-422.

Gascón y Marín, J. (1917). Tratado elemental de Derecho administrativo: principios y legislación española. Madrid: Imprenta Clásica Española.

Gay Armenteros, J. C. (1993). Política y administración en Javier de Burgos. Granada: Centro de Estudios Municipales y de Cooperación Interprovincial.

Gómez de la Serna, P. (1843). Instituciones del derecho administrativo español. Madrid: V. Lalama, 2 vols.

González Alonso, B. (1995). Las raíces ilustradas del ideario administrativo del moderantismo español. En De la Ilustración al liberalismo: Symposium en honor al profesor Paolo Grossi (pp. 157-196). Madrid: Centro de Estudios Constitucionales.

Laferrière, E. (1887-1888). Traité de la juridiction administrative et des recours contentieux. Paris: Berger-Levrault, 2 vols.

Langrod, G. (1957). La ciencia de la Administración Pública en Francia: orígenes y contorno europeo actual y pasado. Revista de Ciencias Sociales, I (3), 495-525.

López Tabar, J. (2001). Los famosos traidores: los afrancesados durante la crisis del Antiguo Régimen (1808-1833). Madrid: Biblioteca Nueva.

Lorente, M. (2009). Un día en la vida del centauro liberal (libertad de los modernos vs. jurisdicción administrativa en la restauración francesa, 1814-1830). Historia $y$ Politica, 22, 15-44.

Lorente, M. y Garriga, C. (2007). Cádiz, 1812: la Constitución jurisdiccional. Madrid: Centro de Estudios Políticos y Constitucionales.

Luis, J. Ph. (2002). L'utopie réactionnaire: épuration et modernisation de l'état dans l'Espagne de la fin de l'Ancien Régime (1823-1834). Madrid: Casa de Velázquez.

Macarel, L. A. (1833). Éléments de droit politique. Paris: Néve.

- (1835). Curso completo de derecho publico general. París: Librería española de Lecointe, 3 vols.

- (1838). Elementos de Derecho político. Madrid: Yenes, 2 vols.

Mannori, L. y Sordi, B. (2001). Storia del diritto amministrativo. Roma-Bari: Laterza.

Marcuello, J. I. (2007). La Constitución de 1845. Madrid: Iustel.

Martí Martínez, M. y Romeo Mateo, M. C. (2006). El juego de los espejos o la ambivalente relación del territorio y la nación. En C. Forcadell y M. C. Romeo (eds.). Provincia y nación. Los territorios del liberalismo (pp. 51-72). Zaragoza: Institución Fernando el Católico.

Martín-Retortillo Baquer, S. (1997). Alejandro Oliván: reflexiones sobre su vida y su obra. Madrid: Civitas.

Nieto, A. (1965). Influencias extranjeras en la evolución de la ciencia española del Derecho administrativo. Anales de la Facultad de Derecho. Universidad de La Laguna, 3 (1), 43-68. (1996). Los primeros pasos del Estado constitucional. Historia administrativa de la regencia de María Cristina de Borbón. Barcelona: Ariel.

Oliván, A. (1843 [1842]). De la administración pública con relación a España. Madrid: Boix, $2^{\mathrm{a}}$ ed. 
Ortiz de Zúñiga, M. (1832). Deberes y atribuciones de los correjidores, justicias, y ayuntamientos de España. Madrid: Jordán, 5 vols.

- (1841). El libro de los Alcaldes y Ayuntamientos. Granada: Sanz.

- (1842). Elementos de derecho administrativo. Granada: Sanz, 3 vols.

Osborne, T. R. (1989). The German Model in France: French Liberals and the Staatswissenchaften, 1815-1848. Jahrbuch für europäische Verwaltungsgeschichte, 1, 123-139.

Pérez Núñez, J. (1998). El primer contenido administrativo de la provincia: los subdelegados. En In memoriam. Estudios dedicados a Antonio María Calero (pp. 101-122). Pozoblanco: Ayuntamiento de Pozoblanco/Diputación de Córdoba.

- (2002). Francisco Agustín Silvela Blanco (1803-1857), ideólogo de la administración centralizada. Revista de Administración Pública, 157, 119-156.

- (2011). Entre el Ministerio de Fomento y el de la Gobernación: los delegados gubernativos de Madrid en la transición a la Monarquía constitucional, 1832-1836. Madrid: UAM-Dykinson.

Pickering, M. (2009). Auguste Comte: An Intellectual Biography. Cambridge: Cambridge University Press, 2 vols.

Posada Herrera, J. de (1843). Lecciones de Administración. Madrid: Establec. Tipogr., 3 vols.

Pro, J. (1992). Estado, geometría y propiedad. Los orígenes del catastro en España (1715-1941). Madrid: CGCCT-Ministerio de Economía y Hacienda.

— (1994). Fraude, statistique et pouvoir dans l'Espagne libérale (1840-1868). Revue d'Histoire Moderne et Contemporaine, XLI (2), 253-268.

- (1996). Las contribuciones de producto antiguas de 1845. En F. Comín y R. Vallejo (dirs.). La reforma fiscal de Mon-Santillán, ciento cincuenta años después (pp. 119-134). Madrid: Instituto de Estudios Fiscales.

(2000). La imagen histórica de la España imperial como instrumento político del nacionalismo conservador. En J. Martínez Millán y C. Reyero (eds.). El siglo de Carlos Vy Felipe II: la construcción de los mitos en el siglo XIX (pp. 217-235). Madrid: Sociedad Estatal para la Conmemoración de los Centenarios de Felipe II y Carlos V, vol. II.

(2008). Innovación del lenguaje y policía de las costumbres: el proyecto de los afrancesados en España. En A. Ávila y P. Pérez Herrero (comps.). Las experiencias de 1808 en Iberoamérica (pp. 231-249). Alcalá de Henares-México: Universidad de Alcalá-Universidad Nacional Autónoma de México.

— (2014). El Derecho y los derechos. En M. Á. Cabrera y J. Pro (eds.). La creación de las culturas políticas modernas, 1808-1833 (pp. 69-95). Madrid-Zaragoza: Marcial Pons Historia-Prensas de la Universidad de Zaragoza.

- (2016a). The Origins of State Bureaucracy in Nineteenth Century Spain. En J. C. Garavaglia, Ch. Lamouroux y M. J. Braddick (eds.). Serve the Power(s), Serve the State. America and Eurasia (pp. 132-167). Newcastle, Cambridge Scholars.

- (2016b). El Estado grande de los moderados en la España del siglo xix. Historia y Politica, 36, 19-48.

Prontuario de las leyes y decretos del Rey Nuestro Señor don José Napoleón I desde el año de 1808. Madrid: Imprenta Real, 1810, $2^{a}$ ed., 3 vols.

Rosanvallon, P. (2007). El modelo politico francés: la sociedad civil contra el jacobinismo, de 1789 hasta nuestros días. Buenos Aires: Siglo XXI. 
Sánchez León, P. (2005). Ordenar la civilización: semántica del concepto de policía en los orígenes de la ilustración española. Política y Sociedad, 42 (3), 139-156.

Santamaría de Paredes, V. (1881). Curso de derecho político según la filosofía politica moderna, la historia general de España y la legislación vigente. Valencia: Ferrer de Orga.

- (1885). Curso de derecho administrativo según principios generales y la legislación actual de España. Madrid: Ricardo Fe.

Santamaría Pastor, J. A. (1973). Sobre la génesis del Derecho Administrativo español en el siglo XIX (1812-1845). Sevilla: Instituto García Oviedo.

Silvela, F. A. (1839). Colección de proyectos, dictámenes y leyes orgánicas, o estudios prácticos de administración. Madrid: Imprenta Nacional.

Solla, J. (2007). Justicia bajo administración (1834-1868). En De justicia de jueces a justicia de leyes: hacia la España de 1870 (pp. 289-324). Madrid: Consejo General del Poder Judicial.

Suárez, F. y Berazaluze, A. M. (eds.) (1968). Documentos del reinado de Fernando VII. Pamplona: Universidad de Navarra, 8 tomos en 22 vols.

Valeriola, T. (1798). Idea general de la policia ó Tratado de policia. Valencia: Benito Monfort.

Vallejo Pousada, R. (2001). Reforma tributaria y fiscalidad sobre la agricultura en la España liberal, 1845-1900. Zaragoza: Prensas Universitarias de Zaragoza.

Vizcaíno Pérez, V. (1781). Tratado de la jurisdiccion ordinaria para direccion, y guia de los alcaldes de España. Madrid: Joachín Ibarra. 